Fidei: Jurnal Teologi Sistematika dan Praktika, Vol. 4, No. 2, Des. 2021

Fidei: Jurnal Teologi Sistematika dan Praktika

Terakreditasi No: 85/M/KPT/2020 (Sinta 4)

e-ISSN: $2621-8135$

http://www.stt-tawangmangu.ac.id/e-journal/index.php/fidei

Vol. 4 No.2 (Des. 2021) hlm: 298-314

p-ISSN: 2621-8151

Diterbitkan Oleh: Sekolah Tinggi Teologi Tawangmangu

\title{
Pendidikan Kristen dalam Keluarga Sebagai Upaya Pembentukan Karakter Remaja
}

\author{
Paskah Parlaungan Purba ${ }^{1{ }^{*}}$ \\ ${ }^{1)}$ Sekolah Tinggi Teologi Basom Batam, Indonesia \\ *) E-mail: paspurba07@gmail.com
}

Diterima: 20 Sep. 2021 Direvisi: 02 Des. 2021

Disetujui: 06 Des. 2021

\begin{abstract}
Abstrak
Persoalan remaja Kristen pada masa globalisasi saat ini sangat rentan dengan kemerosotan karakter. Kemerosotan karakter itu seperti menjadi mementingkan diri sendiri dan gampang terpengaruh negatif dari media sosial. Permasalahan ini menjadi tantangan bagi orang tua Kristen dalam mendidik anak remajanya. Penelitian ini mengkaji Pendidikan Kristen Keluarga dengan Pembentukan Karakter Remaja di GBI Cipta Asri Batam. Metode yang digunakan dalam penelitian ini ialah metode kuantitatif. Teknik pengumpulan data dengan penyebaran kuesioner kepada 30 responden jemaat GBI Cipta Asri Batam. Hasil penelitian menjelaskan bahwa terdapat pengaruh yang signifikan antara Pendidikan Kristen Keluarga terhadap Pembentukan Karakter Remaja. Data menunjukkan bahwa kenakalan remaja berkurang karena pengaruh pelaksanaan Pendidikan Kristen Keluarga, dimana skor yang diperoleh ialah $53,3 \%$ (berada pada kategori cukup). Artinya, terdapat pengaruh yang signifikan Pendidikan Kristen Keluarga terhadap Pembentukan Karakter Remaja.
\end{abstract}

Kata-Kata Kunci: Karakter; Keluarga; Pendidikan Kristen; Remaja.

\section{Abstract}

The problem of Christian teenagers in the current time of globalization is very vulnerable to character slump. The character slump is like being selfish and easily influenced by the negatifs of social media. This problem is a 
challenge for Christian parents in educating their adolescents. For this reason, this study examined Family Christian Education with Youth Character Formation in GBI Cipta Asri Batam. The method used in this study is quantitative method. Data collection technique with the dissemination of questionnaires to 30 respondents of GBI Cipta Asri Batam congregation. The results explain that there is a significant influence between Family Christian Education on Adolescent Character Formation. Data shows that juvenile delinquency is reduced due to the influence of the implementation of Family Christian Education, where the score obtained is $53.3 \%$ (in the sufficient category). That is, there is a significant influence of Family Christian Education on the Formation of Adolescent Character.

Keywords: Adolescent; Character; Christian Education; Family.

\section{Pendahuluan}

Keadaan lingkungan pergaulan remaja dapat mempengaruhi sikap dan perilaku remaja. Jika lingkungan pergaulan remaja mamilki sifat-sifat yang negatif secara otomatis sifat tersebut akan tertular bagi remaja yang bergabung di dalamnya. Lingkungan pergaulan yang positif dan berdasarkan nilai-nilai kekristenan, merupakan area atau lingkungan yang sangat baik bagi perkembangan dan pertumbuhan remaja. Apabila remaja memilih lingkungan dan pergaulan yang baik, maka baik juga hasilnya dalam pembentukan sikap atau karakter. Namun sebaliknya, jika remaja memilih ligkungan pergaulan yang salah, maka hasilnya akan buruk pula dalam pembentukan sikap remaja.

Ditinjau dari segi perkembangannya, masa remaja dapat dikatakan sebagai masa peralihan antara masa anak ke masa pra-dewasa. Setiap remaja yang beranjak atau masuk ke dalam masa ini tentunya sudah memiliki pendirian secara pribadi atau dengan lain sudah susah diatur untuk melakukan sesuatu hal. Sudah tidak diherankan lagi jika orang tua sering mengeluh karena anak remajanya tidak mendengarkan setiap nasihat yang diberikan kepadanya, akibatnya remaja tersebut mengambil jalan yang salah, menganggap bahwa setiap tindakan yang diambil tidak terjerumus dalam kenakalan. Biasanya pada masa perkembangan remaja ini, kenakalan itu berbentuk mengabaikan nasihat dan mengutamakan kehendak diri sendiri. Sejatinya, pihak yang bertanggung jawab terhadap remaja di keluarga ialah orang tua. ${ }^{1}$ Hal ini sejalan dengan Firman Tuhan dalam Amsal 22:6, "Didiklah orang muda menurut jalan yang patut baginya, maka pada masa tuanya tidak akan menyimpang dari pada jalan itu."

${ }^{1}$ Widhi Arief Nugroho, "Peranan Pendidikan Keluarga Tentang Kekudusan Hidup Menurut Roma 12:1-2,” FIDEI: Jurnal Teologi Sistematika dan Praktika 1, no. 2 (2018): 185198. 
Umumnya orang tua mengharapkan anaknya memiliki karakter yang baik. Karakter yang dimaksud, sebagaimana Wahidin menjelaskan, bahwa karakter merupakan tabiat, watak, akhlak, atau kepribadian seseorang yang terbentuk dari hasil internalisasi dari berbagai kebajikan yang diyakini, serta digunakan sebagai landasan untuk cara pandang, berpikir, bertindak, dan bersikap. Sementara itu, kebajikan mencakup nilai, moral, dan norma, seperti jujur, berani bertindak, dapat dipercaya, dan hormat kepada orang lain. ${ }^{2}$ Sejalan dengan itu, Kalis menyajikan ada tujuh kebajikan utama dalam membangun karakter kristiani anak, yaitu belas kasih, empati, penguasaan diri, rasa hormat, toleransi, adil, dan cinta tanah air. ${ }^{3}$

Dalam penelitian Nababan, generasi penerus yang kelak akan mampu menjadi pemimpin bangsa yang diharapkan, dapat menjadikan contoh dalam karakter yang positif berdasarkan nilai-nilai yang berisi kristiani, serta normanorma yang ada dan berlaku dalam Masyarakat. ${ }^{4}$ Namun kenyataanya yang bisa dilihat semakin meningkatnya tingkat kejahatan kenakalan remaja yang tidak terbendung oleh perkembangan teknologi sebagaimana Lastri dalam penelitiannya mengatakan, kenakalan remaja dapat berupa tauran pelajar. Berdasarkan data yang dirilis oleh Komisi Perlindungan Anak Indonesia (2019), menunjukkan angka tauran pelajar di Indonesia kian meningkat datanya dari tahun ke tahun. Misalnya, pada tahun 2017 sebesar 12,9 naik menjadi 14 persen di tahun 2018. ${ }^{5}$ Lebih lanjut, Lastri juga mengatakan dalam tulisanya bahwa remaja melakukan perilaku yang menimbulkan keprihatinan seperti bolos sekolah, tindakan yang sekedar mengganggu (arak-arakan sepeda motor), geng, pencurian, menonton video porno, pelecehan seksual, penyalahgunaan narkoba, bahkan melakukan pembunuhan.

Kemudian dalam penggunaan internet oleh remaja, di satu sisi internet dapat membantu remaja untuk mengetahui segalanya, tetapi yang menjadi persoalan ialah banyak remaja yang salah menggunakan internet. Untuk itu, sangat diperlukan peran orang tua atau figur yang mengerti dan menangani kenakalan remaja ini. Sebab dampak negatif internet dapat merusak perilaku pemakai jika penggunaannya tidak etis dan tidak efektif (menyimpang). Pemakaian internet secara tidak tepat dapat berakibat fatal, khususnya terhadap

2 Unang Wahidin, "Pendidikan Karakter Bagi Remaja," Edukasi Islami: Jurnal Pendidikan Islam 2, no. 3 (2017): 259.

${ }^{3}$ Kalis Stevanus, "Tujuh Kebajikan Utama Untuk Membangun Karakter Kristiani Anak," BIA': Jurnal Teologi dan Pendidikan Kristen Kontekstual 1, no. 1 (June 2018): 80.

${ }^{4}$ A. Lumban Gaol, N. T., \& Nababan, "Kepemimpinan Guru Pendidikan Agama Kristen,” Kelola: Jurnal Manajemen Pendidikan 6, no. 1 (2019): 128.

${ }^{5}$ A. Lastri, S., Hayati, E., \& Nursyifa, "Dampak Kenakalan Remaja Untuk Meningkatkan Kesadaran Dari Bahaya Kenakalan Remaja Bagi Masa Depan,” Jurnal Loyalitas Sosial: Journal of Community Service in Humanities and Social Sciences 2, no. 1 (2020): 16. 
pelajar, yang mudah terpengaruh oleh informasi-informasi atau konten-konten negatif. ${ }^{6}$

Kajian tentang Pendidikan Kristen Keluarga dan pembentukan karakter remaja sudah dilakukan oleh beberapa peneliti. Hasil dari penelitian-penelitian tersebut di antaranya: penelitian Wadi dan Selfina tentang peran orangtua dalam mengajarkan Pendidikan Agama Kristen kepada remaja. Hasil dari penelitian ini mengungkapkan bahwa peran orangtua dalam pendidikan Kristen dalam keluarga terutama kepada remaja, dapat dilakukan dengan cara mengajarkan nilai-nilai firman Tuhan, menjadi figur pendidik, disiplin, memberikan teladan, serta menciptakan keluarga yang bijak dalam bermedia sosial (cyber smart). ${ }^{7}$ Selanjutnya hasil penelitian Rantung, menjelaskan bahwa pola asuh dalam keluarga adalah tugas pendidikan Kristen yang dilakukan di dalam keluarga sebagai pembentukan karakter dan pertumbuhan iman terutama anak-anak. Lebih lanjut ditegaskan bahwa tujuan pola asuh keluarga berdasarkan pendidikan agama Kristen yaitu menghasilkan keluarga-keluarga yang berkarakter seperti: kasih dan kepedulian, memiliki motivasi, serta saling menghargai. ${ }^{8}$ Sejalan dengan itu, hasil penelitian Zega menjelaskan bahwa pengaruh perubahan zaman dan juga kurangnya pemahaman orang tua tentang bagaimana cara membangun spiritualitas anak-anaknya yang sesuai dengan kebutuhan mereka dimasa sekarang, sehingga anak- anak remaja tersebut tidak mempercayai keyakinan dari agamanya sendiri ${ }^{9}$ Hasil penelitian lainnya diungkapkan oleh Talizaro. Ia mengungkapkan bahwa salah satu peran pendidikan Agama Kristen dalam keluarga saat ini adalah mengupayakan kerja sama ayah dan ibu dalam mendidik anak serta menciptakan keharmonisan dalam keluarga. ${ }^{10}$ Terakhir, penelitian Asmat Purba, yang menyadarkan para orang tua yaitu sebagai pendidik Kristen dalam keluarga yang mengayomi dan mendidik anak-anak, serta mampu menyikapi krisis sebagai akibat pandemi Covid-19. ${ }^{11}$

Data hasil penelitian di atas umumnya menggunakan metode kualitatif. Kemudian teknik pengumpulan data yang digunakan ialah literatur atau kajian

${ }^{6}$ Eny Suprihatin, "Kontekstualisasi Roma 12:2 Dalam Keniscayaan Dunia Digital," Fidei: Jurnal Teologi Sistematika dan Praktika 4, no. 1 (2021): 117-139.

${ }^{7}$ Elsyana Nelce Wadi and Elisabet Selfina, "Peran Orang Tua Sebagai Keluarga Cyber Smart Dalam Mengajarkan Pendidikan Kristen Pada Remaja GKII Ebenhaezer Sentani Jayapura Papua," Jurnal Jaffray 14, no. 1 (2016): 77.

${ }^{8}$ Djoys Anneke Rantung, "Pendidikan Agama Kristen Untuk Keluarga Menurut Pola Asuh Keluarga Ishak Dalam Perjanjian Lama,” Jurnal Shanan 3, no. 2 (2019): 63-77.

9 Yunardi Kristian Zega, "Pendidikan Agama Kristen Dalam Keluarga: Upaya Membangun Spiritualitas Remaja Generasi Z," Luxnos: Jurnal Sekolah Tinggi Teologi Pelita Dunia 7, no. 1 (2021): 105-116.

10 Talizaro Tafonao, "Peran Pendidikan Agama Kristen Dalam Keluarga Terhadap Perilaku Anak," Edudikara: Jurnal Pendiidkan dan Pembelajaran 3, no. 2 (2018): 121-133, https://ojs.iptpisurakarta.org/index.php/Edudikara/article/view/92.

11 Asmat Purba, "Tanggung Jawab Orang Tua Kristen Sebagai Pendidik Dalam Menyikapi Dampak Pandemi Covid-19," EPIGRAPHE: Jurnal Teologi dan Pelayanan Kristiani 4, no. 1 (2020): 86-97. 
pustaka. Untuk membedakan penelitian ini dengan penelitian-penelitian sebelumnya adalah peneliti menggunakan penelitian lapangan dengan menggunakan metode kuantitatif. Adapun penelitian ini dilakukan di jemaat GBI Cipta Asri Batam. Peneliti akan mengkaji sejauh mana pengaruh Pendidikan Kristen Keluarga terhadap pembentukan karakter remaja di Jemaat GBI Asri Batam. Dari rumusan penelitian ini, peneliti akan membahas pembentukan karakter melalui keluarga dan mengkaji penanggulangan kenakalan remaja di GBI Cipta Asri. Tujuan dari pembentukan karakter remaja melalui keluarga diharapkan dapat memecahkan masalah-masalah yang terjadi terutama kenakalan remaja.

\section{Metode Penelitian}

Penelitian ini menggunakan metode kuantitatif. Peneliti menggunakan populasi accessible, dimana peneliti menyebarkan angket kepada beberapa sampel yang mewakili populasi. Populasi yang peneliti ambil dari keluarga jemaat GBI Cipta Asri Batam sebanyak 150 orang. Sampel sebanyak 20\%, artinya $20 \%$ dari 150 orang adalah 30 orang, dimana sampel diambil dengan teknik random (acak). Dengan pertimbangan bahwa jumlah tersebut cukup homogen untuk menghasilkan data yang diperlukan sebagai objek sebagai data penelitian yang kemudian digunakan untuk menguji data dan menarik kesimpulan. Untuk memperoleh data penelitian, peneliti menggunakan teknik non test dengan menggunakan instrumen pengumpulan data berupa angket, sehingga responden tinggal memilih alternatif jawaban dari instrumen yang sebelumnya telah diuji reliabilitas dan validitas. Skor tertinggi dalam butir angket 1-20 menjadi 4 × $20=80$, dan skor terendah 1 × $20=20$. Teknik analisis data jika memenuhi persyaratan analisis yaitu berdistrubusi normal dan linier maka diuji dengan statistika parametric dan jika tidak memenuhi persyaratan analisis maka digunakan non parametrik.

\section{Pembahasan dan Hasil}

\section{Pendidikan Kristen dalam Keluarga}

Secara historis pendidikan Kristen dapat dikatakan muncul sejak jaman Tuhan Yesus atau dalam Perjanjian Baru. Alkitab menjadi pedoman kepada orang percaya dalam Perjanjian Lama yang dimulai sejak terpanggilnya Abraham menjadi nenek moyang umat pilihan Tuhan, bahkan PAK berpokok kepada Allah sendiri, karena Allah yang menjadi pendidik Agung bagi umatNya. ${ }^{12}$ Melalui informasi ini, PAK menjadi suatu pengajaran yang sangat

${ }^{12}$ E. G. dan I. H. Enklaar Homrighausen, Pendidikan Agama Kristen (Jakarta: BPK Gunung Mulia, 2014), 130. 
penting kepada umat kristiani yang mengenal Tuhan Yesus. Mulai dari Perjanjian Lama sampai kepada Perjanjian Baru, PAK sudah mulai diberikan. PAK merupakan perintah dari Tuhan Yesus Kristus yang disebut dengan Amanat Agung dalam Matius 28:19-20, PAK merupakan tindak lanjut setelah pembaptisan. Sebab setiap orang yang telah dibaptis harus diajar melakukan segala sesuatu yang diperintahkan Tuhan Yesus. ${ }^{13}$

Pendidikan Kristen dalam keluarga merupakan dasar bagi seluruh pendidikan lainnya dalam masyarakat umat Tuhan pada jaman Perjanjian Lama. Dalam surat yang dikirim nabi Yeremia dari Yeruslem kepada para pemimpin bangsa Yahudi yang ada dalam tawanan di babel, berisi ajakan untuk membangun rumah, membentuk rumah tangga, melahirkan dan membesarkan anak-anak, dalam rasa takut akan Tuhan, supaya umat Tuhan jangan mati merana, melainkan tetap berkembang karena justru dalam keluarga Yahudi itu terletak harapan dan jaminan akan masa depan yang hendak didatangkan Tuhan kelak. ${ }^{14}$ Keluarga Kristen sudah diajarkan sejak semula untuk mulai belajar tentang Tuhan dari bangsa Israel karena merekalah bangsa yang pertama mengenal Tuhan. Pengajaran tentang agama Kristen memang harus dimulai dari dalam Alkitab. Pengajaran orang tua mengenai Pendidikan Kristen hanya bisa didapat di gereja dan pengetahuan masa kecil mereka di dalam gereja. Tuhan Yesus juga mengungkapkan bahwa gereja berperan penting sebagai wadah restorasi umat (pendamaian). Rasul Paulus juga menyadari komitmen dan pengorbanan Tuhan Yesus bagi gereja-Nya agar dapat membentuk suatu umat, memelihara mereka, menjaga tetap kudus, dan tidak bercacat di hadapan Allah (Ef. 5:25, 26). Gereja tidak boleh berdiam diri dalam pengajaran kepada jemaatNya terutama kepada remaja. Seperti yang ditegaskan oleh Stevanus dan Sitepu, bahwa gereja melalui keluarga memiliki tanggung jawab dalam dalam menanamkan nilai-nilai kristiani dalam perkembangan karakter anak. ${ }^{15}$

\section{Hakikat Karakter Remaja}

Kata remaja berasal dari terjemahan bahasa Inggris adolescence, dan bahasa Latin adolescere, yang memiliki arti tumbuh atau tumbuh menjadi dewasa. Selanjutnya, Kamus Umum Bahasa Indonesia (KBBI), kata remaja memiliki tiga arti yakni, mulai dewasa, sudah hampir umur untuk kawin, dan masa muda. Dalam arti luar, remaja merupakan suatu masa yang sedang mencapai kematangan mental, emosional, sosial, dan fisik. Selain itu, aspek spiritualitas dan moralitas merupakan hal yang sangat mendasar dalam

${ }^{13}$ Ibid.

${ }^{14}$ Ibid., 143.

15 Kalis Stevanus dan Nathanail Sitepu, "Strategi Pendidikan Kristen Dalam Pembentukan Warga Gereja Yang Unggul Dan Berkarakter Berdasarkan Perspektif Kristiani," SANCTUM DOMINE: Jurnal Teologi 10, no. 1 (2020). 
kehidupan anak. ${ }^{16}$ Untuk itu, remaja merupakan masa dimana pribadi melakukan integrasi dengan masyarakat dewasa. Dimana anak tidak lagi merasa di bawah tingkat orang-orang yang lebih tua, melainkan berada dalam tingkatan yang sama, yaitu sekurang-kurangnya dalam masalah hak. Integrasi dalam masyarakat dewasa mempunyai aspek efektif, atau masa puber, dimana terjadi perubahan intelektual yang mencolok.

Di usia dua belas tahun, masih dianggap sebagai anak-anak, masih tergantung pada orang tua. Batasan golongan termasuk usia remaja yaitu usia berkisar 12-21 tahun bagi perempuan dan 13-22 tahun bagi laki-laki. Usia remaja merupakan usia yang sulit, terutama karena usia itu merupakan tahap kehidupan saat banyak orang mulai menyadari kenyataan bahwa hidup ini sulit. ${ }^{17}$ Remaja adalah individu yang sedang berada pada masa peralihan dari masa anak-anak menuju masa dewasa yang ditandai dengan perkembangan yang sangat cepat dari aspek fisik, psikis dan sosial. Masa remaja adalah masa yang tidak bisa dilupakan, karenamasa perubahan yang drastis dari keadaan tergantung menjadi keadaan mandiri. Seseorang dalam masa transisi dari anakanak ke masa dewasa, masa di saat individu berkembang akan mengalami tahapan perkembangan psikologis serta pola identifikasi dari anak menjadi dewasa, yang kemudian terjadi peralihan dari ketergantungan sosial ekonomi yang penuh kepada situasi yang mandiri. ${ }^{18}$ Pada periode atau masa tumbuh seorang remaja dalam masa transisi periode anak-anak ke masa dewasa, akan meliputi perkembangan pada tahap persiapan memasuki periode dewasa.

Periode remaja disebut juga sebagai masa social hunger atau kehausan sosial, yang ditandai dengan adanya keinginan bergaul, serta diterima pada lingkungan kelompok sebayanya (peer group). Dengan keinginan yang ambivalen, disatu sisi adanya keinginan untuk lepas dari ketergantungan, serta dapat menentukan pilihannya sendiri. Usia remaja memiliki berbagai ciri yang khas, untuk membedakannya dengan masa-masa sebelum atau masa sesudahnya. Usia remaja memunculkan berbagai kebutuhan dan emosi, serta tumbuhnya kekuatan dan kemampuan fisik yang lebih jelas dan daya pikir yang matang. Masa muda sedang bertumbuh atau menuju dewasa. Individu yang sedang berada pada masa peralihan dari masa anak-anak menuju masa dewasa dan ditandai dengan perkembangan yang sangat cepat dari aspek fisik, psikis dan sosial. ${ }^{19}$

${ }^{16}$ Fredik Melkias Boiliu, "Pembelajaran Pendidikan Agama Kristen Dalam Keluarga Di Era Digital," TE DEUM: Jurnal Teologi dan Pengembangan Pelayanan 10, no. 1 (2020): 107119.

${ }^{17}$ Palentina Rian Pratiwi, Kunci Meraih Kebahagiaan Remaja (Jakarta: Peica, 2015), 2.

${ }^{18}$ Clara Sr Lina, Panduan Menjadi Remaja Percaya Diri (Jakarta: Nobel Edumedia, 2015), 3 .

${ }^{19}$ E. D. Papalia and R. T. Feldman, Meyelami Perkembangan Manusia; Experience Human Development (Jakarta: Salemba Humanika, 2014), 32. 


\section{Ciri Masa Remaja}

Masa remaja dalam perkembangannya memiliki ciri yang khas. Ciri-ciri remaja yang khas tersebut adalah sebagai berikut: ${ }^{20}$ pertama, masa remaja sebagai priode yang penting. Pada prinsipnya, semua tahapan yang dilalui manusia pada hakikatnya penting. Namun derajat kepentingan masing-masing tahapan tidak sama. Ada tahapan yang lebih penting dari tahapan perkembangan lainnya. Masa remaja boleh dikatakan periode yang lebih penting dari pada masa akhir anak-anak karena perubahan yang terjadi pada masa remaja ini lebih banyak mempengaruhi sikap dan prilaku remaja secara langsung dan cepat dibandingkan masa akhir anak-anak. Kemampuan adaptasi dan rintanganrintangan yang dihadapi remaja untuk segera memahami jati dirinya menjadi dinamika yang unik dan berliku. Hal inilah yang menjadikan masa remaja sebagai periode yang penting. Sebagai remaja, akan menganggap masa atau periode ini bukan hanya penting, akan tetapi sekaligus menjadi periode yang penuh dengan kenangan yang tidak mudah untuk dilupakan.

Kedua, masa remaja adalah sebagai periode peralihan. Masa peralihan merupakan masa perpindahan atau perubahan dari satu masa ke masa berikutnya. Masa remaja juga merupakan masa meninggalkan masa anak-anak, selanjutnya siap memasuki masa dewasa. Pada masa peralihan akan menimbulkan suasana tidak jelas dan keraguan, baik di dalam pribadi remaja sendiri maupun orang-orang dewasa yang memandang remaja dari luar peralihan. ${ }^{21}$ Ketidakjelasan itu disebabkan masih bercampurnya masa usia anakanak dalam diri remaja, yang mulai bertumbuhnya sikap seperti orang dewasa, walaupun baru bersifat samar belaka. Oleh sebab itu, remaja adalah anak-anak yang sudah masuk tahap besar, serta orang dewasa yang masih seperti kekecilan.

Ketiga, usia remaja sebagai priode perubahan. Masa remaja merupakan periode perubahan yang merata serta sama beratnya. Dengan kata lain, perubahan yang terjadi secara fisik diiringi bersamaan dengan berat kualitas dengan perubahan seperti mental, sikap, dan prilaku. Perubahan seperti emosi lebih sensitif dan emosional dibandingkan anak-anak. Kemudian juga dengan perubahan tubuh, minat, dan peran. Perubahan pada tubuh terjadi pada awal remaja, tepatnya saat puber. Pada saat terjadi kematangan fisik menandai munculnya kemampuan reproduksi. Perubahan ini akan cukup mengagetkan serta menyulitkan remaja, khususnya di masa atau usia awal remaja. Kini citacita itu harus didaur ulang lagi oleh remaja berkenaan dengan terjadinya perubahan fisik yang dialami, serta adanya tuntutan peran dari lingkungan, yang paling penting disini adalah peran orang tua. Selanjutnya, perubahan nilai-nilai. Seiring dengan perubahan seperti minat dan peran, pada usia anak-anak, seperti memiliki banyak teman adalah sangat penting. Masa remaja penilaian itu akan

\footnotetext{
${ }^{20}$ S.W. Sarwono, Psikologi Remaja (Jakarta: Raja Grafindo Persada, 2016), 45-46.

${ }^{21}$ Imam Ratrioso, Remaja Unggul Kamukah Itu? (Jakarta: Nobel Edumedia, 2013), 18-
} 19. 
berubah, bukan pada jumlah teman yang dimiliki, tetapi sejauh mana teman atau pergaulan memberikan kontribusi yang berarti pada dirinya. Kemudian terdapat perubahan ambivalensi, yang artinya terdapat sikap yang mendua, mau-mau tapi juga tidak mau. Di satu sisi remaja banyak memiliki tuntutan, di sisi lain ada rasa takut yang besar. Sikap mendua inilah menjadi persoalan konflik internal yang cukup pelik di usia remaja.

Keempat, periode remaja sebagai usia yang bermasalah. Usia remaja sebagai usia yang sulit disebabkan oleh dua hal. Kedua hal tersebut ialah masa anak-anak dulu, karena tradisi dan kebiasaan, masalah diselesaikan oleh guru atau orang dewasa, sehingga saat remaja tidak punya pengalaman dan keberanian untuk menyelesaikan masalah sendiri. Masalah berikutnya, remaja merasa sudah mandiri, sehingga menolak campur tangan orang dewasa dalam membantu masalahnya. Kedua hal inilah yang menyebabkan permasalahan demi permasalahan datang silih berganti.

Kelima, masa remaja sebagi masa pencarian identitas. Masa remaja dikatakan masa mencari identitas, ${ }^{22}$ karena remaja ingin melepaskan diri dari campur tangan orang tua maupun orang dewasa. Dimana dianggap telah melindungi dan melakukan campur tangan terlalu jauh terhadap kehidupan pribadinya. Dalam pencarian identitas remaja akan menyeleksi figur-figur idola yang dianggap telah mewakili impiannya. Figur-figur dapat berasal dari apa saja, seperti: artis, bintang olah raga, tokoh politik, aktivis kemanusiaan, dan lain sebagainya. Selain pencarian figur, remaja juga melakukan upaya pencarian identitas dirinya dengan ikut terlibat dalam kelompok-kelompok yang biasa disebut geng. Remaja merasa eksistensinya dihargai di dalam kelompok tarsebut karena persamaan-persamaan pandangan dan nilai yang dianut dalam kelompoknya. Kelemahan pribadi remaja sebagai individu dapat ditutupi dengan adanya sikap solidaritas antar sesama angota kelompok remaja. Akhirnya pribadinya menyatu bersama karakter dalam kelompok, cita-cita, maupun pandangan hidup yang disesuaikan dengan cita-cita dan pandangan kelompok. Bagaimanapun kelompok itu berjalan, apakah mengarah kepada hal yang positif ataukah negatif akan tetap diikuti. Solidaritas dalam kelompok sangat tinggi melebihi perhatian remaja pada kepentingan pribadinya. Kasus kenakalan remaja, misalnya perkelahian berangkat dari kondisi seperti ini.

Keenam, periode remaja merupakan usia yang menimbulkan ketakutan. Yang dimaksud dengan usia yang dapat menimbulkan ketakutan, yaitu adanya stereotip (penyamarataan) yang berlaku di masyarakat. Dimana masa remaja penuh dengan masalah dan kenegatifan, sehingga menyebabkan timbulnya rasa takut di kalangan orang dewasa dalam mengatasi masalah remaja. Stereotip ini terus akan terwujud karena hal-hal yang negatif yang dilakukan remaja selalu dibicarakan di hampir semua media melebihi hal-hal positif. Ketidakseimbangan

${ }^{22}$ Ibid. 
informasi antara nilai-nilai positif dan negatif yang dilakukan remaja, secara tidak disadari membentuk pemahaman di alam bawah sadar remaja. Pemahaman seperti ini pula yang kemudian menimbulkan rasa ketakutan remaja terhadap dirinya sendiri. ${ }^{23}$

Ketujuh, usia remaja sebagai masa yang tidak realistis. Remaja biasanya cenderung melihat segala sesuatu dengan apa yang ia inginkan, bukan sebagaimana adanya. Remaja ingin orang tuanya, sahabatnya, gurunya, pacarnya, dan semua yang berhubungan dengan dirinya berjalan sesuai dengan apa yang ia inginkan. Apabila yang diinginkan itu tidak menjadi kenyataan, ia akan mudah kecewa dan terbawa emosi. Dalam hal respon remaja pada saat menghadapi kenyataan yang tidak sesuai, akan menimbulkan banyak permasalahan yang dialami oleh remaja. Jika dimotivasi akan membebaskan sebuah renaissance penemuan maupun pengajaran. ${ }^{24}$ Respon itu bisa berupa emosi, frustrasi, atau putus asa yang pada akhirnya menumbuhkan prilakuprilaku yang negatif tanpa arahan yang jelas.

Kedelapan, usia remaja sebagai ambang masa dewasa. Maksud dari ambang masa dewasa disini ialah adanya batas-batas antara masa remaja dan masa dewasa. ${ }^{25}$ Batas-batas samar yang ada akan menjembatani masa peralihan dua masa yang berbeda, yang kemudian memaksa remaja untuk segera mengidentikkan dirinya sebagai orang yang benar-benar siap menjadi orang dewasa. Berbagai perubahanpun akan diupayakan demi memenuhi penerimaan orang lain, bahwa ia telah pantas menjadi orang dewasa. Misalnya, dengan mengubah cara berpakaian menjadi lebih modis dan trendi. Meskipun semua itu telah dilakukan, remaja tetap saja merasa kurang atau belum pantas disebut orang dewasa. Ia akan melakukan apa saja agar citra atau image dirinya menunjukkan bahwa ia adalah orang yang telah siap dewasa.

\section{Kenakalan Remaja}

Kenakalan merupakan suatu perbuatan buruk yang dilakukan individu secara sadar maupun tidak sadar. Apabila tidak dicegah dapat berakibat lebih fatal dan meresahkan banyak orang. Masa remaja disebut juga sebagai masa yang memunculkan pemberontakan, menampilkan beragam gejolak emosi, menarik diri dari keluarga, serta mengalami banyak masalah, baik masalah di rumah, sekolah, maupun di lingkungan pertemanannya. Kenakalan remaja pada masa modern ini sudah melebihi batas yang sewajarnya. Terjadi kasus anak di bawah umur yang sudah mengenal cabut dari sekolah, mencuri, menbohongi orang tua, tawuran, merokok, terlibat dalam lingkaran narkoba, seks bebas, dan

\footnotetext{
${ }^{23}$ Ibid.

${ }^{24}$ James. R. Evans, Berpikir Kreatif (Jakarta: Bumi Aksara, 2011), 5.

${ }^{25}$ Ibid., 21-22.
} 
terlibat banyak tindakan kriminal lainnya. ${ }^{26}$ Meningkatnya tingkat kriminal di Indonesia tidak hanya dilakukan oleh orang dewasa, akan tetapi banyak juga usia remaja jika dibandingkan tindakan kriminal orang dewasa. Motivasi remaja sederhana dan mudah dipahami dari kalangan remaja. Tindakan kenakalan remaja sangat beraneka ragam dan bervariasi dan misalnya: pencurian yang dilakukan oleh seorang remaja, hanya untuk memberikan hadiah kepada mereka yang disukainya dengan maksut membuat kesan impresif yang baik atau mengagumkan. Akibatnya, banyak orang tua mengeluhkan perilaku anakanaknya yang tidak dapat diatur, bahkan terkadang bertindak melawan orang tua.

Dari hasil pengumpulan data melalui instrumen angket yang dapat dilihat dari data di bawah ini, maka diperoleh hasil penelitian variable Pendidikan Kristen Keluarga (X) dan variable Pembentukan Karakter Remaja (Y) yang disajikan dalam tabel sebagai berikut:

Tabel 1. Hasil Penelitian Variabel X dan Variabel Y

\begin{tabular}{llllll}
\hline No. & $\mathrm{X}$ & $\mathrm{Y}$ & No. & $\mathrm{X}$ & $\mathrm{Y}$ \\
\hline 1 & 64 & 70 & 16 & 69 & 73 \\
\hline 2 & 72 & 76 & 17 & 71 & 80 \\
\hline 3 & 74 & 79 & 18 & 69 & 71 \\
\hline 4 & 71 & 54 & 19 & 62 & 52 \\
\hline 5 & 71 & 61 & 20 & 61 & 69 \\
\hline 6 & 62 & 75 & 21 & 62 & 54 \\
\hline 7 & 64 & 57 & 22 & 73 & 60 \\
\hline 8 & 67 & 75 & 23 & 65 & 76 \\
\hline 9 & 60 & 56 & 24 & 70 & 62 \\
\hline 10 & 73 & 61 & 25 & 47 & 60 \\
\hline 11 & 63 & 60 & 26 & 58 & 69 \\
\hline 12 & 57 & 61 & 27 & 67 & 77 \\
\hline 13 & 79 & 77 & 28 & 73 & 76 \\
\hline 14 & 62 & 60 & 29 & 61 & 52 \\
\hline 15 & 61 & 56 & 30 & 60 & 53 \\
\hline
\end{tabular}

Dari data yang disajikan di atas, dapat dideskripsikan hasil penelitian pada masing-masing variabel, dimana variabel $\mathrm{X}$ adalah Pendidikan Kristen Keluarga dan variabel Y adalah Pembentukan Karakter Remaja.

Pertama, deskripsi data variabel Pendidikan Kristen Keluarga (X). Untuk mengetahui gambaran dari data variabel Pendidikan Kristen Keluarga, maka disajikan harga M (rata-rata) dan standart deviasi (SD). Distribusi frekuensi dan gambar histogram dari skor variabel Pendidikan Kristen Keluarga (X) dapat diberikan sebagai berikut:

${ }^{26}$ Stefanus M. Marbun Lumban Gaol and Kalis Stevanus, "Pendidikan Seks Pada Remaja," FIDEI: Jurnal Teologi Sistematika dan Praktika 2, no. 2 (2019): 325-343. 
Tabel 2. Distribusi Frekuensi Variabel X

\begin{tabular}{llllllll}
\hline $\mathbf{K}$ & $\mathbf{I k}$ & $\mathbf{F O}$ & $\mathbf{F H}$ & $\mathbf{f}_{\mathbf{0}}-\mathbf{f}_{\mathbf{h}}$ & $\left.\mathbf{( f}_{\mathbf{0}}-\mathbf{f}_{\mathbf{h}}\right)^{\mathbf{2}}$ & $\frac{\left(f_{0}-f_{h}\right)^{2}}{f_{h}}$ & \multirow{F}{*}{$\mathbf{F r}(\boldsymbol{\%})$} \\
\hline 1 & $78-84$ & 1 orang & 0,6 & 0,4 & 0,16 & 0,27 & 3,3 \\
\hline 2 & $72-77$ & 5 orang & 4,2 & 0,8 & 0,64 & 0,15 & 16,7 \\
\hline 3 & $66-71$ & 8 orang & 10,2 & $-2,2$ & 1,44 & 0,47 & 26,7 \\
\hline 4 & $60-65$ & 13 orang & 10,2 & 2,8 & 7,84 & 0,77 & 43,3 \\
\hline 5 & $54-59$ & 2 orang & 4,2 & $-2,2$ & 4,84 & 1,15 & 6,7 \\
\hline 6 & $48-53$ & 1 orang & 0,6 & 0,4 & 0,16 & 0,27 & 3,3 \\
\hline & Jumlah & $\mathbf{3 0}$ orang & & & & $\mathbf{3 , 0 8}$ & $\mathbf{1 0 0}$ \\
\hline
\end{tabular}

\section{Keterangan:}

\section{$\mathbf{K}=$ Kelas}

FO=Frekwensi Observasi

\section{IK= Interval Kelas}

FH=Frekwensi Harapan

Dengan berpedoman pada ketentuan, jika $X_{o^{2}}($ chi-kuadrat $)<\mathrm{X}_{\mathrm{t}^{2}}$ dengan taraf signifikansi 5\% dengan derajat kebebasan $(\mathrm{DK})=\mathrm{n}-1=6-1=5$, dimana diketahui $\mathrm{X}_{\mathrm{t}^{2}}=11,07$ dan dari tabel di atas diperoleh bahwa $X_{o^{2}}=3,08(3,08$ $<11,07)$, maka disimpulkan data variabel ubahan $X$ berdistribusi secara normal.

Dengan memperhatikan tabel di atas, maka dapat diketahui besarnya frekuensi observasi dan frekensi relatif untuk masing-masing kelas interval. Ternyata jumlah subjek penelitian yang memiliki skor $78-84$ sebanyak 1 orang $(3,3 \%)$, skor $72-77$ sebanyak 5 orang $(16,7 \%)$, skor $66-71$ sebanyak 8 orang $(26,7 \%)$, skor $60-65$ sebanyak 13 orang $(43,3 \%)$, skor $54-59$ sebanyak 2 orang $(6,7 \%)$ dan skor nilai $48-53$ sebanyak 1 orang $(3,3 \%)$.

Selanjutnya untuk mengetahui hubungan antara frekuensi observasi dengan interval kelas maka dapat ditunjukkan melalui gambar histogram di bawah ini:

Gambar 1. Histogram Hubungan antara Frekuensi Obsevarsi dengan Interval Kelas Variabel Pendidikan Kristen Keluarga (X)

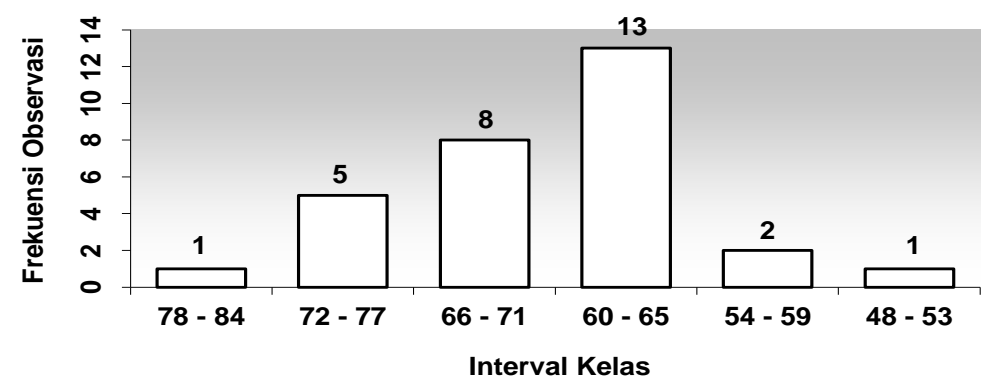


Distribusi frekuensi dan gambar histogram dari skor Pembentukan Karakter Remaja (Y) dapat diberikan sebagai berikut:

Tabel 3. Distribusi Frekuensi Pembentukan Karakter Remaja (Y)

$$
\mathbf{K} \quad \mathbf{I K} \quad \mathbf{F O} \quad \mathbf{F K} \quad \mathbf{f}_{\mathbf{0}}-\mathbf{f}_{\mathbf{h}} \quad \underset{\left.\mathbf{f}_{\mathbf{h}}\right)^{\mathbf{2}}}{\left(\mathbf{f}_{\mathbf{0}}\right.}-\frac{\left(f_{0}-f_{h}\right)^{2}}{f_{h}} \underset{\mathbf{( \% )}}{\mathbf{F r}}
$$

\begin{tabular}{llllllll}
\hline 1 & $83-90$ & 0 orang & 0,6 & 0,6 & 0,36 & 0,6 & 0 \\
\hline 2 & $74-82$ & 9 orang & 4,2 & 4,1 & 16,81 & 4,0 & 30 \\
\hline 3 & $65-73$ & 5 orang & 10,2 & $-5,2$ & 27,04 & 2,65 & 16,7 \\
\hline 4 & $56-64$ & $\begin{array}{l}11 \\
\text { orang }\end{array}$ & 10,2 & 0,8 & 0,64 & 0,06 & 36,6 \\
\hline 5 & $47-55$ & 5 orang & 4,2 & 0,8 & 0,64 & 0,15 & 16,7 \\
\hline 6 & $38-46$ & 0 orang & 0,6 & 0,6 & 0,36 & 0,6 & 0 \\
\hline & $\begin{array}{l}\text { Jumla } \\
\text { h }\end{array}$ & $\begin{array}{l}\text { 30 } \\
\text { orang }\end{array}$ & & & & $\mathbf{7 , 4 6}$ & $\mathbf{1 0 0}$ \\
\hline
\end{tabular}

Keterangan:

$$
\mathbf{K}=\text { Kelas }
$$

FO=Frekwensi Observasi

Dengan berpedoman pada ketentuan, jika $X_{o^{2}}($ chi-kuadrat $)<\mathrm{X}_{\mathrm{t}^{2}}$ dengan taraf signifikansi $5 \%$ dengan derajat kebebasan $(\mathrm{DK})=\mathrm{n}-1=6-1=5$, dimana diketahui $\mathrm{X}_{\mathrm{t}^{2}}=11,07$ dan dari tabel di atas diperoleh bahwa $\mathrm{X}_{0^{2}}=7,64(7,64<$ 11,07), maka disimpulkan data variabel ubahan $\mathrm{Y}$ (Pembentukan Karakter Remaja) berdistribusi secara normal.

Dengan memperhatikan tabel di atas, maka dapat diketahui besarnya frekuensi observasi dan frekwensi relatif untuk masing-masing kelas interval. Ternyata jumlah subjek penelitian yang memiliki skor 83 - 90 tidak ada (0\%), skor $74-82$ sebanyak 9 orang (30\%), skor $65-73$ sebanyak 5 orang $(16,7 \%)$, skor 56 - 64 sebanyak 11 orang $(36,6 \%)$, skor 47 - 55 sebanyak 5 orang $(16,7 \%)$ dan skor nilai 38 - 46 tidak ada $(0 \%)$.

Selanjutnya untuk mengetahui hubungan antara frekuensi observasi dengan interval kelas maka dapat ditunjukkan melalui gambar histogram dibawah ini:

Gambar 2. Histogram Hubungan antara Frekuensi Obsevarsi dengan Interval Kelas Variabel Pembentukan Karakter Remaja (Y) 


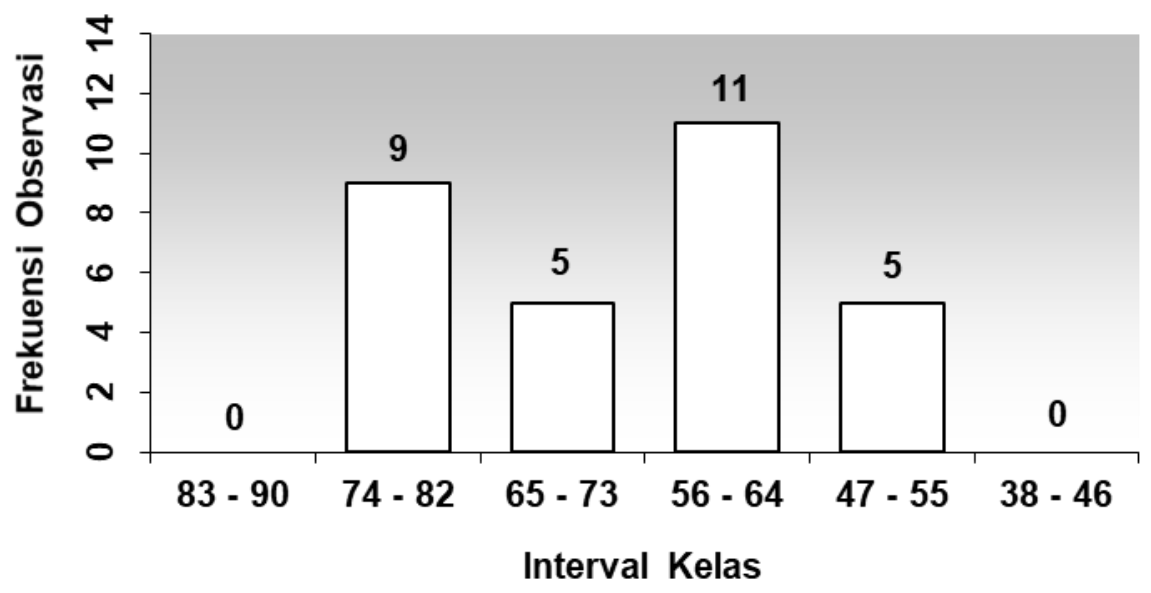

Kedua, tingkat kecenderungan variabel penelitian. Tingkat kecenderungan variabel Pembentukan Karakter Remaja. Untuk mengetahui tingkat kecenderungan variabel maka diketahui terlebih dahulu harga rata-rata skor ideal (Mi) dan simpangan baku (Sdi). Dengan mengacu pada perhitungan harga rata-rata skor ideal (Mi) dan simpangan baku (SDi), maka tingkat kecenderungan Pendidikan Kristen Keluarga (X) dapat dilihat pada tabel dibawah ini.

Tabel 3. Tingkat Kecenderungan Variabel Pembentukan Karakter Remaja (X)

\begin{tabular}{llllll}
\hline Kelas & Interval & $\begin{array}{l}\text { Frekuensi } \\
\text { Observasi }\end{array}$ & $\begin{array}{l}\text { Frekuensi } \\
(\mathbf{\%})\end{array}$ & relatiff & kategori \\
\hline 1 & $65 \mathrm{ke}$ atas & 15 & $50 \%$ & Tinggi \\
\hline 2 & $50 \mathrm{~s} / \mathrm{d} 64$ & 14 & $46,7 \%$ & Cukup \\
\hline 3 & $35 \mathrm{~s} / \mathrm{d} 49$ & 1 & $3,3 \%$ & Kurang \\
\hline 4 & $34 \mathrm{ke}$ bawah & 0 & $0 \%$ & Rendah \\
\hline & Jumlah & $\mathbf{3 0}$ orang & $\mathbf{1 0 0 \%}$ & \\
\hline
\end{tabular}

Dari tabel terlihat bahwa jumlah responden yang termasuk kategori tinggi sebanyak 15 orang (50\%), kategori cukup 14 orang (46,7\%), kategori kurang 1 orang $(3,3 \%)$ dan rendah tidak ada $(0 \%)$. Dari kategori tersebut terlihat bahwa frekuensi observasi dua kelas bagian atas lebih besar dari frekuensi observasi dua kelas bagian bawah, berarti tingkat kecenderungan variabel Pendidikan Kristen Keluarga (X) dinyatakan tinggi.

Ketiga, tingkat kecenderungan variabel Pembentukan Karakter Remaja (Y). Dengan mengacu pada perhitungan harga rata-rata skor ideal (Mi) dan simpangan baku (SDi), maka tingkat kecenderungan variabel Pembentukan Karakter Remaja (Y) dapat dilihat dari tabel dibawah ini. 
Tabel 4. Tingkat Kecenderungan Variabel Pembentukan Karakter Remaja (Y)

\begin{tabular}{|c|c|c|c|c|}
\hline Kelas & Interval & $\begin{array}{l}\text { Frekuensi } \\
\text { Observasi }\end{array}$ & $\begin{array}{l}\text { Frekuensi relative } \\
(\%)\end{array}$ & kategori \\
\hline 1 & 65 ke atas & 14 & $46,7 \%$ & Tinggi \\
\hline 2 & $50 \mathrm{~s} / \mathrm{d} 64$ & 16 & $53,3 \%$ & Cukup \\
\hline 3 & $35 \mathrm{~s} / \mathrm{d} 49$ & 1 & $0 \%$ & Kurang \\
\hline 4 & 34 ke bawah & 0 & $0 \%$ & Rendah \\
\hline
\end{tabular}

Dari tabel terlihat bahwa jumlah responden yang termasuk kategori tinggi sebanyak 14 orang (46,7\%), kategori cukup 16 orang (53,3\%), kategori kurang 1 orang $(0 \%)$ dan rendah tidak ada $(0 \%)$. Dari kategori tersebut terlihat bahwa frekuensi observasi dua kelas bagian atas lebih besar dari frekuensi observasi dua kelas bagian bawah, berarti tingkat kecenderungan variabel Pembentukan Karakter Remaja (Y) dinyatakan tinggi.

Dari hasil olah data variabel Pendidikan Kristen Keluarga (X) dan variabel Pendidikan Karakter Remaja (Y) menunjukkan hasil yang tinggi. Artinya, terdapat pengaruh yang signifikan antara Pendidikan Kristen Keluarga dengan Pembentukan Karakter Remaja. Hal ini sejalan dengan teori dan hasil penelitian terdahulu yang dilakukan oleh Wadi dan Selfina, serta Talizaro, yang menjelaskan bahwa Pendidikan Kristen dalam Keluarga sangat penting dalam pembentukan karakter anak atau remaja. Demikian halnya dengan hasil penelitian Yonatan. Ia mengungkapkan bahwa membangun kerohanian dalam keluarga merupakan hal yang penting, dan dapat dilakukan dengan memahami landasan dan tujuan pendidikan agama Kristen yang memperlengkapi kehidupan keluarga dalam kerohanian yang semakin berkenan dihadapan Tuhan dan menjadi berkat bagi sesama anggota keluarga. ${ }^{27}$ Dengan demikian, orang tua dalam perlu memperhatikan aspek Pendidikan Kristen bagi anak-anaknya, sehingga terbentuk pola perilaku dan karakter yang baik dalam kehidupan keluarga.

\section{Simpulan}

Hasil penelitian mengungkapkan bahwa terdapat pengaruh yang signifikan antara Pendidikan Kristen Keluarga dengan Pembentukan Karakter Remaja di GBI Cipta Asri Batam. Untuk itu, hendaknya pelaksanaan Pendidikan Kristen Keluarga dapat dioptimalkan. Dengan adanya pelaksanaan Pendidikan Kristen Keluarga, maka kenakalan Remaja GBI Cipta Asri semakin berkurang. Kenakalan remaja berkurang karena pengaruh pelaksanaan Pendidikan Kristen Keluarga, dimana skor yang diperoleh ialah 53,3\% (berada pada kategori

27 Yonatan Alex Arifianto, "Pentingnya Pendidikan Kristen Dalam Membangun Kerohanian Keluarga Di Masa Pandemi Covid-19," REGULA FIDEI: Jurnal Pendidikan Agama Kristen 5, no. 2 (2020): 94-106, http://christianeducation.id/ejournal/index.php/regulafidei/article/view/52. 
cukup). Artinya, terdapat pengaruh yang signifikan Pendidikan Kristen Keluarga terhadap Pembentukan Karakter Remaja.keluarga Kristen dapat lebih berperan dalam membimbing anak khususnya remaja. Karena keluarga adalah pusat perubahan sehingga kenakalan remaja dapat dihindari terutama di era digital yang penuh dengan tantangan.

\section{Daftar Pustaka}

Arifianto, Yonatan Alex. "Pentingnya Pendidikan Kristen Dalam Membangun Kerohanian Keluarga Di Masa Pandemi Covid-19." REGULA FIDEI: Jurnal Pendidikan Agama Kristen 5, no. 2 (2020).

Boiliu, Fredik Melkias. "Pembelajaran Pendidikan Agama Kristen Dalam Keluarga Di Era Digital.” TE DEUM: Jurnal Teologi dan Pengembangan Pelayanan 10, no. 1 (2020): 107-119.

Evans, James. R. Berpikir Kreatif. Jakarta: Bumi Aksara, 2011.

Homrighausen, E. G. dan I. H. Enklaar. Pendidikan Agama Kristen. Jakarta: BPK Gunung Mulia, 2014.

Lastri, S., Hayati, E., \& Nursyifa, A. "Dampak Kenakalan Remaja Untuk Meningkatkan Kesadaran Dari Bahaya Kenakalan Remaja Bagi Masa Depan." Jurnal Loyalitas Sosial: Journal of Community Service in Humanities and Social Sciences 2, no. 1 (2020).

Lina, Clara Sr. Panduan Menjadi Remaja Percaya Diri. Jakarta: Nobel Edumedia, 2015.

Lumban Gaol, N. T., \& Nababan, A. "Kepemimpinan Guru Pendidikan Agama Kristen." Kelola: Jurnal Manajemen Pendidikan 6, no. 1 (2019).

Lumban Gaol, Stefanus M. Marbun, and Kalis Stevanus. "Pendidikan Seks Pada Remaja." FIDEI: Jurnal Teologi Sistematika dan Praktika 2, no. 2 (2019): 325-343.

Nugroho, Widhi Arief. "Peranan Pendidikan Keluarga Tentang Kekudusan

Hidup Menurut Roma 12:1-2." FIDEI: Jurnal Teologi Sistematika dan Praktika 1, no. 2 (2018): 185-198.

Papalia, E. D., and R. T. Feldman. Meyelami Perkembangan Manusia; Experience Human Development. Jakarta: Salemba Humanika, 2014.

Pratiwi, Palentina Rian. Kunci Meraih Kebahagiaan Remaja. Jakarta: Peica, 2015.

Purba, Asmat. "Tanggung Jawab Orang Tua Kristen Sebagai Pendidik Dalam Menyikapi Dampak Pandemi Covid-19.” EPIGRAPHE: Jurnal Teologi dan Pelayanan Kristiani 4, no. 1 (2020): 86-97. 
314 Fidei: Jurnal Teologi Sistematika dan Praktika, Vol. 4, No. 2, Des. 2021

Rantung, Djoys Anneke. "Pendidikan Agama Kristen Untuk Keluarga Menurut Pola Asuh Keluarga Ishak Dalam Perjanjian Lama.” Jurnal Shanan 3, no. 2 (2019): 63-77.

Ratrioso, Imam. Remaja Unggul Kamukah Itu? Jakarta: Nobel Edumedia, 2013.

Sarwono, S.W. Psikologi Remaja. Jakarta: Raja Grafindo Persada, 2016.

Shochib, Moh. Pola Asuh Orang Tua: Dalam Membantu Anak Mengembangkan Displin Diri. Jakarta: Rineka Cipta, 2015.

Stevanus, Kalis. "Tujuh Kebajikan Utama Untuk Membangun Karakter Kristiani Anak.” BIA': Jurnal Teologi dan Pendidikan Kristen Kontekstual 1, no. 1 (June 2018): 80.

Stevanus, Kalis, and Nathanail Sitepu. "Strategi Pendidikan Kristen Dalam Pembentukan Warga Gereja Yang Unggul Dan Berkarakter Berdasarkan Perspektif Kristiani." SANCTUM DOMINE: Jurnal Teologi 10, no. 1 (2020).

Suprihatin, Eny. "Kontekstualisasi Roma 12:2 Dalam Keniscayaan Dunia Digital." Fidei: Jurnal Teologi Sistematika dan Praktika 4, no. 1 (2021): 117-139.

Tafonao, Talizaro. "Peran Pendidikan Agama Kristen Dalam Keluarga Terhadap Perilaku Anak." Edudikara: Jurnal Pendiidkan dan Pembelajaran 3, no. 2 (2018).

Wadi, Elsyana Nelce, and Elisabet Selfina. "Peran Orang Tua Sebagai Keluarga Cyber Smart Dalam Mengajarkan Pendidikan Kristen Pada Remaja GKII Ebenhaezer Sentani Jayapura Papua.” Jurnal Jaffray 14, no. 1 (2016): 77.

Wahidin, U. "Pendidikan Karakter Bagi Remaja." Edukasi Islami : Jurnal Pendidikan Islam 2, no. 3 (2017).

Zega, Yunardi Kristian. "Pendidikan Agama Kristen Dalam Keluarga: Upaya Membangun Spiritualitas Remaja Generasi Z." Luxnos: Jurnal Sekolah Tinggi Teologi Pelita Dunia 7, no. 1 (2021). 